\title{
Penyuluhan dan Pelatihan Olahan Sagu Menjadi Produk Brownies Dan Cookies Pada Tim Penggerak Pkk Desa Purwosari Kecamatan Tomoni Timur Kabupaten Luwu Timur
}

\author{
Rahmawati $^{1}$, Firmansyah ${ }^{2}$, Asriyanti Syarif ${ }^{3}$ dan Sitti Arwati ${ }^{4}$
}

\author{
${ }^{1}$ Email : rahmawati.hodi@unismuh.ac.id \\ Prodi : Agribisnis, Fakultas Pertanian, Universitas Muhammadiyah Makassar \\ 2Email : firmansyah@unismuh.ac.id \\ Prodi : Agribisnis, Fakultas Pertanian, Universitas Muhammadiyah Makassar \\ ${ }^{3}$ Email : asriyanti.syarif@unismuh.ac.id \\ Prodi : Agribisnis, Fakultas Pertanian, Universitas Muhammadiyah Makassar \\ ${ }^{4}$ Email : sittiarwati@unismuh.ac.id \\ Prodi : Agribisnis, Fakultas Pertanian, Universitas Muhammadiyah Makassar
}

\begin{abstract}
Abstrak. Pengabdian kepada masyarakat ini dilatarbelakangi oleh potensi sagu yang cukup besar pada Desa Purwosari, Kecamatan Tomoni Timur, Kabupaten Luwu Timur namun belum berkembang secara maksimal, terutama di kalangan ibu-ibu. Selain itu, permasalahan lainnya adalah adanya ketidaktauan mitra bahwa sagu dapat diolah menjadi produk brownies dan cookies selain produk makanan; waktu luang yang banyak dan kurang termanfaatkan oleh kegiatan yang bernilai positif dan produktif; keinginan mitra Ibu-ibu PKK melakukan pemberdayaan perempuan khususnya dalam pengolahan sagu untuk menambah penghasilan keluarga. Pengabdian kepada masyarakat ini bermitra dengan ibu-ibu PKK Purwosari. Jenis produk olahan yang dipilih adalah brownies dan cookies sagu karena pembuatannya cukup gampang dan bahan-bahannya mudah diperoleh.Pengabdian ini akan memperkenalkan kandungan gizi dan manfaat sagu dalam bentuk penyuluhan dan dilanjutkan dengan pemberian pelatihan pengolahan sagu menjadi cookies serta memberikan teknik penggunaan kemasan yang menarik yang dapat memberikan nilai jual yang pada akhirnya akan menumbuhkembangkan jiwa kewirausahaan pada masyarakat.Penyuluhan dan pelatihan yang dilakukan memberikan nilai pengetahuan, keterampilan, nilai tambah olahan produk dari sagu, dan memberikan jiwa wirausaha bagi ibu-ibu PKK untuk dapat membuka industri skala rumah tangga dengan olahan sagu menjadi cookies dan brownies. Menjadikan sagu memiliki nilai jual apalagi dikemas dengan kemasan yang menarik dan diberikan label.
\end{abstract}

Kata Kunci: sagu, brownies, cookies

DOI: http://dx.doi.org/10.35914/tomaega.v3i1.278

Article history:

Received November 4, 2019; Revised November 10, 2019; Accepted Desember 20, 2019 


\section{PENDAHULUAN}

Tanaman Sagu yang biasa dikenal juga dengan nama tanaman rumbia sangat berpotensi besar untuk dikembangkan di Indonesia tetapi pada umumnya belum diusahakan secara intensif seperti penghasil karbohidrat lainnya. Sagu di Indonesia merupakan tanaman yang berada di kawasan hutan dan tidak dilakukan tindakan usahatani (pembudidayaan) atau berada pada tanah di wilayah marginal atau kawasan rawa-rawa. Potensi tanaman sagu di Indonesia diperkirakan 1,1 juta ha, setara dengan 5,81-8,51 juta ton pati sagu kering/tahun (Bantacut, 2011).

Luwu Timur merupakan salah satu daerah penghasil sagu, di Sulawesi Selatan. Sagu banyak tumbuh dikawasan hutan, dan di manfaatkan sebagai produk makanan selain nasi. Sagu dikonsumsi masyarakat dala bentuk tepung yang kaya dengan karbohidrat karena mengandung zat pati, namun sangat miskin gizi lainnya. Ini terjadi akibat tingginya kandungan pati didalam teras batang maupun pada proses pemanenannya. Pada seratus gram sagu kering setara dengan 355 kalori, terkandung 94 gra karbohidrat, 0,2 gram protein, 0,5 gam serat, $10 \mathrm{mg}$ kalsium, 1,2 mg besi dan lemak, karoten, tiamin dan asam askorbat dalam jumlah yang sangat kecil (Wikipedia.org).

Kandungan gizi yang potensial pada sagu dan manfaatnya bagi kesehatan, menjadikan sagu sebagai alternatif makanan sehat pengganti beras yang dapat mendukung program ketahanan pangan.

Ketahanan pangan menjadi salah satu dari sebelas prioritas pembangunan nasional. Guna endukung pencapaian ketahanan pangan tersbut, di Kementerian Pertanian dilaksanakan program yang disebut empat sukses pertanian, yang terdiri dari pencapaian swasembada lima komoditas pangan penting, peningkatan diversifikasi pangan, peningkatan nilai tambah, daya saing komoditas pertanian, dan peningkatan kesejahteraan petani menuju ketahanan pangan Indonesia berkelanjutan 2025 (Suryana, 2014).

Produk sagu memiliki potensi besar sebagai sumber pangan namun belum dimanfaatkan secara maksimal. Kurangnya minat masyarakat untuk mengelolah sagu karena rendahnya kemampuan untuk menghasilkan sagu yang lebih untuk kebutuhan masyarakat lokal (Irnawati dkk, 2018).

Sagu sebagai salah bahan makanan yang mendukung ketahanan pangan nasional sampai saat ini masih menjadi primadona dan kebanggaan masyarakat, khususnya di Kecamatan Tomoni Kabupaten Luwu Timur. Nilai produksi sagu selama dua tahun terakhir (2016-2017) mengalami peningkatan dari 26,46 ton menjadi 29,96 ton (Badan Pusat Statistik Kabupaten Luwu Timur, 2018). Hal ini merupakan peluang besar bagi pemerintah daerah setempat untuk pengembangan sagu. Selanjutnya, Sagu diolah menghasilkan tepung setelah melewati proses pengendapan. Tepung dari sagu yang kemudian diolah menjadi produk makanan dan penganan (cookies dan brownies). 


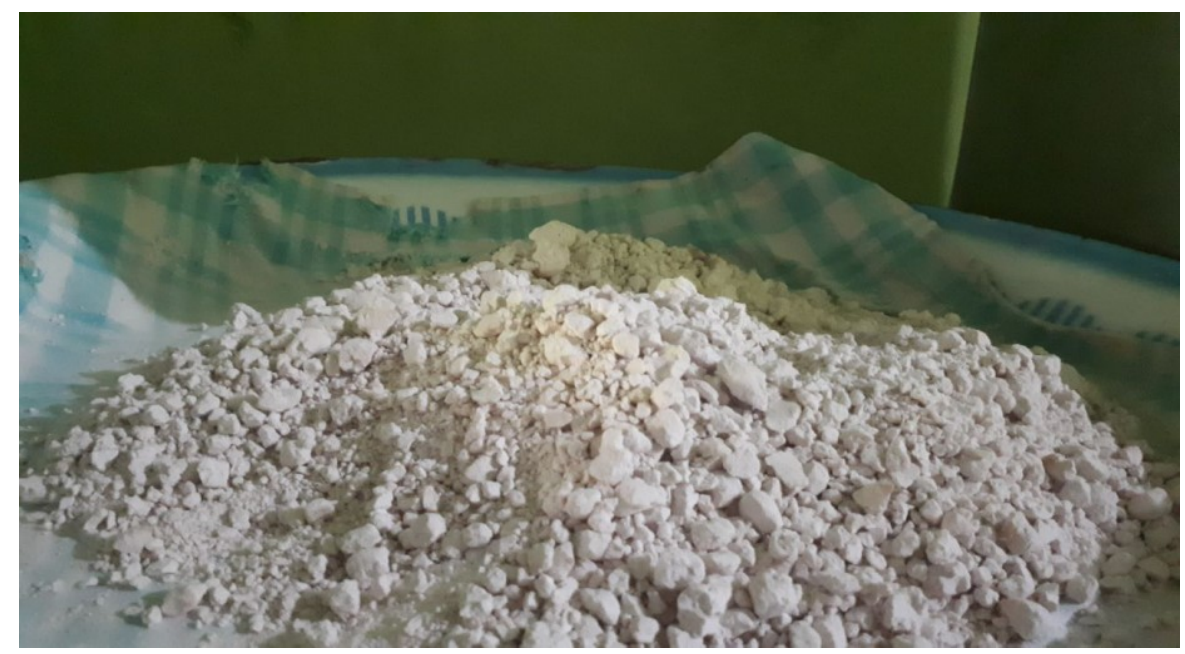

Gambar 1. Tepung Sagu yang siap diolah menjadi produk cookies dan Brownies

Sagu dalam bentuk tepung di wilayah Luwu biasa memanfaatkan sebagai bahan baku pembuatan makanan tradisional, seperti: kappurung, bagea,ongol-ongol, dange. Potensi sagu didaerah ini sangat baik dan hanya dimanfaatkan sebagai produk makanan. Oleh karena itu, Program pengabdian kepada masyarakat ini hadir untuk menambah pengetahuan mitra yakni Tim Penggerak PKK di Desa Purwosari, Kecamatan Tomoni Timur, Kabupaten Luwu Timur yang dapat meningkatkan penghasilan keluarga dan juga memanfaatkan waktu luang dengan kegiatan yang bernilai positf dan produktif dengan pembuatan brownies dan cookies yang dapat juga dimanfaatkan sebagai alternatif usaha untuk membuka usaha skala kecil (skala rumah tangga).

Berdasarkan analisis situasi dan hasil diskusi dengan mitra, dapat disimpulkan dan disepakati beberapa pokok permasalahan yakni:

a. Adanya ketidaktauan mitra bahwa sagu dapat diolah menjadi produk brownies dan cookies selain produk makanan.

b. Waktu luang yang banyak dan kurang termanfaatkan oleh kegiatan yang bernilai positif dan produktif.

c. Keinginan mitra melakukan pemberdayaan perempuan khususnya dalam pengolahan sagu untuk menambah penghasilan keluarga dan menjadikan usaha kreatif.

\section{METODE PELAKSANAAN}

Metode pelaksanaan kegiatan ini dilaksanakan sebagai upaya pemberdayaan masyarakat khususnya Tim Penggerak PKK pada Desa Purwosari, Kecamatan Tomoni Timur, Kabupaten Luwu Timur melalui tahapan-tahapan sebagai berikut:

a. Sosialisasi program pelatihan untuk menyatukan persepsi pengusul dan mitra dalam pelaksanaan program.

b. Setelah dicapai kesepakatan antara pengusul dengan mitra, maka tahapan berikutnya adalah mengadakan penyuluhan atau pembekalan materi mengenai nilai gizi dan manfaat sagu bagi kesehatan yang dapat menjadi alternatif bahan makanan. 
c. Persiapan alat dan bahan yang akan digunakan untuk proses pengolahan sagu menjadi produk brownies dan cookies.

d. Alat yang digunakan adalah: baskom, oven, mixer, kompor gas, cetakan kue, talenan, spatula, ember.Sedangkan bahan-bahan yang digunakan adalah: telur, gula putih, vanili, susu bubuk, tepung sagu, susu coklat bubuk, Susu Kental Manis, baking powder, soda kue, minyak sayur, air, santan, keju, margarin, butter.

e. Pelaksanaan proses demonstrasi memerlukan waktu empat jam untuk dua jenis produk olahan.

f. Pembuatan Bolu coklat/brownies mengikuti tahapan-tahapan sebagai berikut: telur dan gula putih dikocok; tepung terigu, sagu, susu bubuk, vanili, baking soda, minyak sayur, dan air kemudian diaduk hingga rata; Loyang diolesi dengan mentega dan toping, Adonan dikukus selama 25 menit.

g. Pembuatan kue kering sagu keju/cookies mengikuti langkah-langkah sebagai berikut: menyangrai tepung sagu kurang lebih 10 menit dan didinginkan; mengocok gula, butter, dan margarin sampai rata kurang lebih 2 menit; memasukkan kuning telur dan santan diaduk dengan mixer sampai tercampur rata, kemudian keju dimasukkan hingga rata; memasukkan tepung sagu, dan diaduk dengan spatula; mencetak adonan; memanggang adonan 20-25 menit dengan suhu $150^{\circ}$.

h. Setelah proses demonstrasi selesai, peserta kegiatan dapat mencicipi dan merasakan hasil buatannya dan dapat dipraktekkan langsung di rumah. Setelah kegiatan ini, diharapkan mereka dapat memanfaatkan waktu luang dengan kegiatan positif dan produktif yang dapat menambah penghasilan keluarga.

i. Pemberian informasi tentang kemasan untuk mengemas produk olahan agar dapat menjadi produk higienis, menarik, dan memberikan nilai jual.

\section{HASIL DAN PEMBAHASAN}

Kegiatan pengabdian Kepada Masyarakat diadakan di Kantor Desa Purwosari pada hari Jumat Tanggal 13 September 2019. Kegiatan ini terlaksana bekerjasama dengan kelompok Ibu-ibu PKK pada Desa Purwosari, Kecamatan Towoti Timur, Kabupaten Luwu Timur.

Pelaksanaan pelatihan diawali dengan sambutan yang dilakukan oleh Sekretaris Desa mewakili Kepala Desa Purwosari, kemudian dilanjutkan dengan sambutan ketua BPP Kecamatan Towoti Timur, Kabupten Luwu Timur. Kegiatan ini disambut antusias oleh ibuibu PKK Desa Purwosari karena baru pertama kalinya ada kegiatan penyuluhan dan pelatihan, selain itu olahan yang dibuat adalah tepung sagu, yang merupakan komoditas andalan dari daerah Luwu (Luwu Utara dan Luwu Timur).

Menurut sambutan ibu ketua BPP Kecamatan Towoti, selama ini ibu PKK hanya mengenal olahan sagu dengan cara membuat kapurung.Belum ada olahan untuk pembuatan kue (brownies) dan Cookies.Sehingga kerjasama dengan ibu PKK ini membuka wawasan baru dan memberikan keterampilan bagi mereka serta dapat dijadikan ladang usaha dari olahan sagu. 
Pembangunan masyarakat desa melalui proses penyuluhan dan pelatihan merupakan salah satu usaha pembangunan untuk meningkatkan kesejahteraan masyarakat dan memberikan kemandirian bagi desa dalam proses otonomi daerah. Menurut Almasri dan Devi Reswimar (2014), menyatakan bahwa pembangunan masyarakat pedesaan merupakan perwujudan pembangunan otonomi daerah dalam rangka pemerataan pembangunan dan kesejahteraan masyarakat.

Penyuluhan adalah bentuk kegiatan yang dilaksanakan dengan memberikan informasi tentang tanaman sagu, manfaat sagu, kandungan gizi dari tanaman sagu. Selama ini mereka hanya mengetahui bahwa sagu dapt dikonsumsi sebagai produk makanan. Oleh karena itu penyampaian informasi melalui proses penyuluhan untuk membuka pola pikir dan meningkatkan wawasan pada ibu-ibu PKK di Desa Purwosari,Kecamatan Tomoni, Kabupaten Luwu Timur.

Kegiatan pelatihan dilakukan dengan membagi dua kelompok ibu-ibu PKK. Satu kelompok membuat brownies dan satu kelompok membuat cookies. Sebelum kegiatan pelatihan diperlihatkan bahan dan alat yang digunakan. Mereka memperhatikan dengan seksama, dan menurut mereka bahan-bahan tersebut selain tepung sagu mudah didapatkan di pasar dan swalayan yang ada disekitar Luwu Timur.

Kegiatan pelatihan dengan memperagakan cara pembuatan brownies dan cookies. Kegiatan pengolahan sagu menjadi brownies dilakukan secara interaktif dengan memberikan games menarik pada pelaksanaan pembuatan kedua olahan dari sagu. Tujuan pemberian games agar ibu-ibu PKK lebih bersemangat mengikuti kegiatan pelatihan dan suasana lebih hidup karena pelaksanaan kegiatan disiang hari selepas shalat jumat yang berdampak peserta dapat mengantuk.

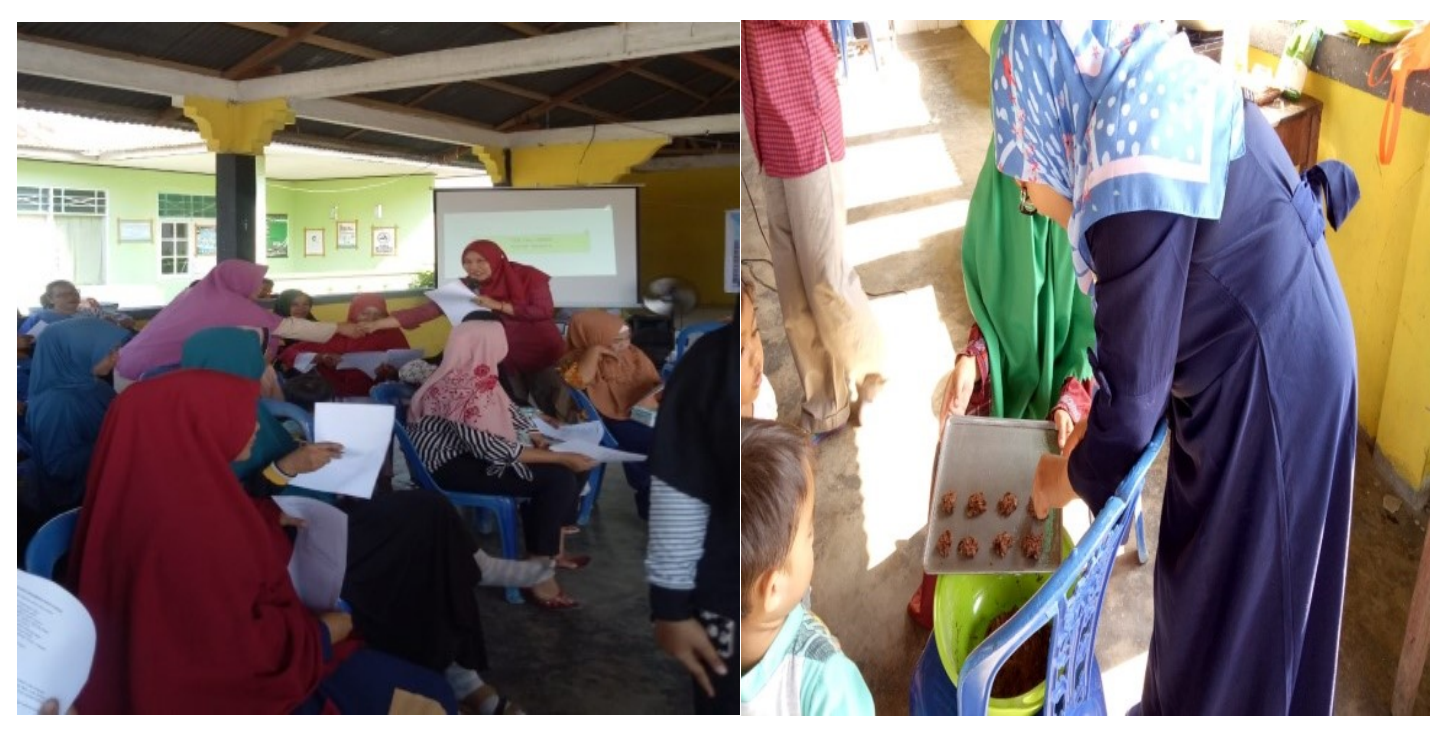

Gambar 2. Proses Penyuluhan dan Pelatihan olahan Sagu

Satu persatu langkah pembuatan brownies dan cookies dilakukan serta menjelaskan dengan detail ukuran-ukuran bahan yang digunakan. Setelah bahan-bahan dicampur dan 
dimasak dengan cara dikukus dan dibakar. Maka ibu-ibu PKK yang telah membantu pelaksanaan kegiatan ini mencoba cita rasa dari produk yang dibuat. Dan mereka mengatakan enak dan ini merupakan inovasi baru dalam olahan cookies dan brownies.

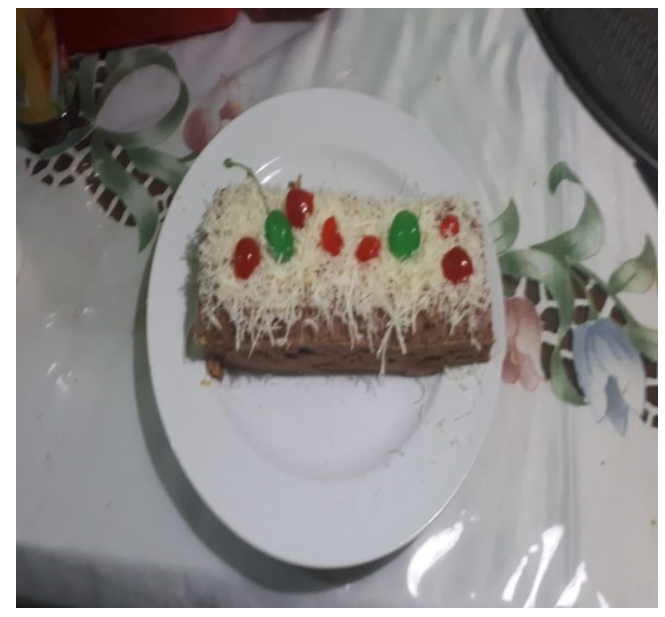

(Brownies Sagu)

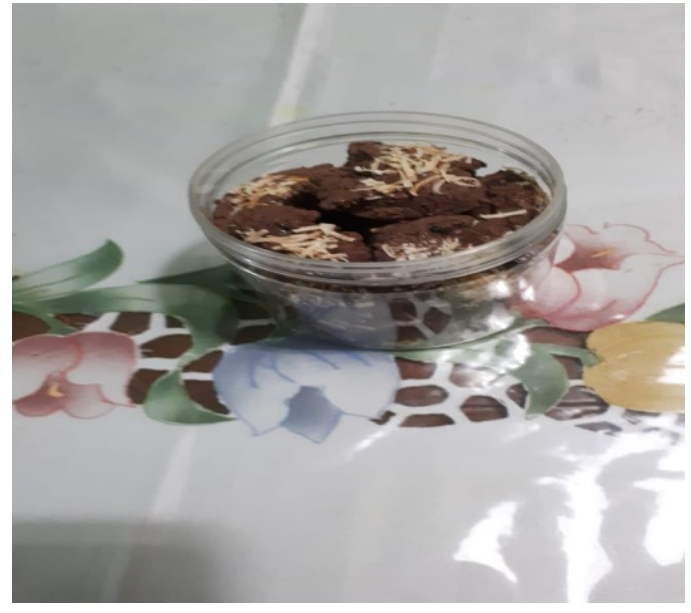

(Cookies Sagu)

Gambar 3. Hasil Pelatihan Produk

Proses pelatihan produk telah dilakukan, dilanjutkan dengan memberikan teknis cara pengemasan dan kemasan yang digunakan untuk brownies dan cookies. Kemasan yang dilakukan dengan kemasan plastik yang kedap udara dan diberikan label produk yang dibuat.

Pelatihan dilakukan dengan membangun komunikasi dengan mitra kerena komunikasi adalah sejumlah informasi yang disampaikan dalam sebuah kelompok. Hal ini senada yang diunggkapkan oleh Arifin (2006), komunikasi memerlukan proses interaksi dengan orangorang yang terlibat dalam upaya penyampaian informasi.

Pelatihan ini dilakukan sebagai upaya pemberdayaan perempuan. Upaya pemberdayaan dimaksudkan dengan merubah pola pikir, merubah perempuan (ibu-ibu PKK) dari peningkatan pengetahuan, wawasan, serta keterampilan. Hal ini senada yang diunggapkan oleh Mardikanto (1999), pemberdayaan dapat dilakukan dengan cara penyuluhan, salah satu maksud dari penyuluhan merubah masyarakat menjadi memiliki pengetahuan dan keterampilan, selain itu pemberdayaan merupakan upaya melepaskan diri dari perangkap kemiskinan dengan kata lain memandirikan. Penyuluhan dan pelatihan yang dilakukan memberikan nilai pengetahuan, keterampilan, nilai tambah olahan produk dari sagu, dan memberikan jiwa kewirausahaan bagi ibu-ibu PKK untuk dapat membuka industri skala rumah tangga dengan olahan sagu menjadi cookies dan brownies yang bisa memupuk kemandirian pada ibu-ibu PKK di desa ini. Menjadikan sagu memiliki nilai jual apalagi dikemas dengan kemasan yang menarik dan diberikan label.

Sagu yang dapat diolah menjadi produk brownies dan cookies merupakan penerapan teknologi sederhana dan proses industrialisasi dengan cara pemberian informasi dan keterampilan kepada mitra. Pada proses industrialisasi pertanian memiliki peluang pasar 
karena adanya jumlah penduduk yang besar yang perlu dipacu adalah peningkatan daya beli dengan cara pemberian kemasan dan label pada produk yang dibuat. Pembuatan produk dari hasil pertanian dalam rangka industrialisasi pertanian menurut Fatah (2006), membutuhkan keterampilan dan menumbuhkan industri.
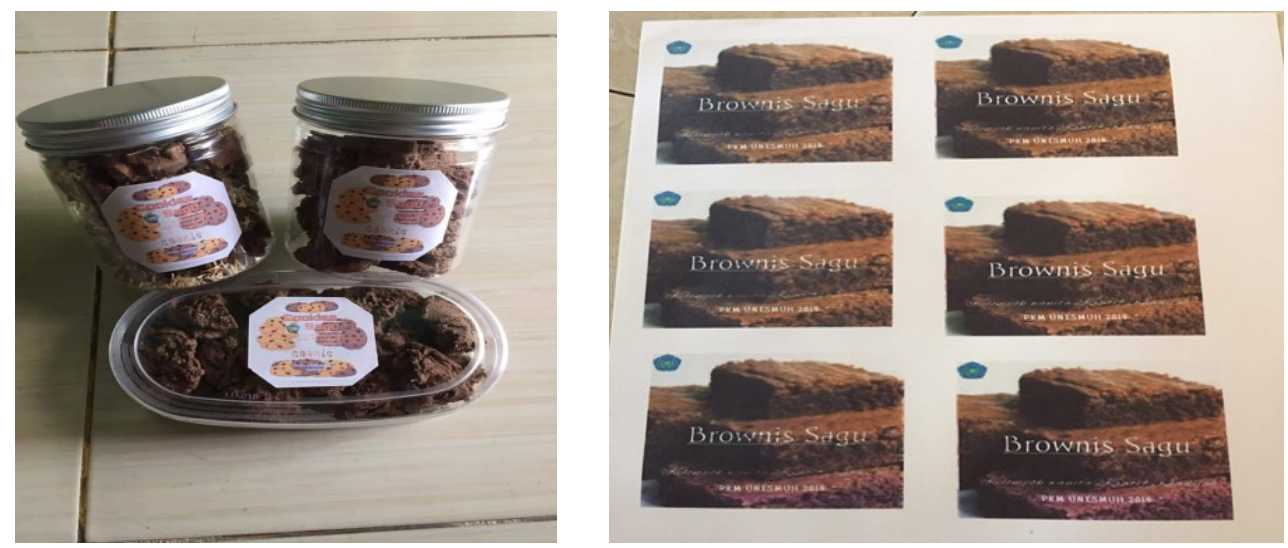

(a). Produk Cookies yang dikemas dan dilabel (b). Contoh label untuk kemasan brownies

Gambar 4. Produk yang Sudah Dikemas dan Dilabel

Ibu-ibu PKK umunya adalah ibu rumah tangga, sehingga dengan adanya pelatihan dapat memberikan motivasi bagi mereka untuk membuka usaha walaupun dalam skala kecil dan merupakan industri rumah tangga (home industry) serta menumbuhkan jiwa kewirausahaan. Hal ini senada yang diunggapkan oleh Khaeriyah (2018), upaya pelathan untuk menumbuhkan jiwa kewirausahaan yang akan menumbuhkan ekonomi produktif yang mampu menambah pendapatan keluarga.

Pemberian informasi tentang kemasan dan pemberian label merupakan rangkaian akhir dari pelaksanaan kegiatan penyuluhan dan pelatihan produk olahan sagu.Pemberian informasi menjadi penting, karena agar produk higienis, memberikan identitas produk yang dibuat dengan adanya pelabelan, memberikan bentuk yang bagus karena produk dikemas rapi sehingga dapat menarik konsumen untuk membeli serta sebagai langkah membuat industri kreatif dari olahan sagu.

\section{SIMPULAN}

a. Mitra menjadi lebih paham mengenai olahan produk makanan berbahan dasar sagu terutama dalam pembuatan brownies dan cookies, terbukti dengan tingginya antuasiasme peserta mengikuti kegiatan ini.

b. Peserta kegiatan dan mitra semakin menyadari akan pentingnyaa menggunakan waktu untuk kegiatan yang bernilai positif dan produktif, khususnya dalam pengolahan sagu menjadi brownies dan cookies.

c. Semakin tingginya keinginan dan minat mitra membentuk kelompok usaha kreatif khususnya dalam pengolahan sagu untuk menambah penghasilan keluarga. 


\section{UNGKAPAN TERIMA KASIH}

Kami haturkan terima kasih kepada LP3M (Lembaga Penelitian dan Pengabdian Kepada Masyarakat) Universitas Muhammadiyah Makassar atas kerjasamanya dalam kegiatan Pengabdian Kepada Masyarakat tahun anggaran 2019.

\section{DAFTAR PUSTAKA}

Arifin, Anwar., 2006. Ilmu Komunikasi sebuah Pengantar Ringkas. Rajawali Pers, Jakarta.

Badan Pusat Statistik Kabupaten Luwu Timur. 2018. Luwu Timur dalam Angka 2018. Pemerintah Kabupaten Luwu Timur.

Bantacut,T. 2011. Sagu: Sumberdaya untuk Penganekaragaman Pangan Pokok. Penebar Swadaya: Jakarta.

Almasri dan Devi Deswimar., 2014. Peran Program Pemberdayaan Masyarakat Desa dalam Pembangunan Pedesaan. Jurnal El-Riyasah, Juni 2014 Volume 5 No. 1 Universitas Islam Negeri Sultan Syarif Kasim Riau, Riau.

Fatah, Luthfi.,2006. Dinamika Pembangunan Pertanian dan Pedesaan. Jurusan Sosek Fakultas Pertanian, Universitas Lambung Mangkurat dengan Pustaka Banua. Cetakan Pertama, September 2006.

http://id.m.wikipedia.org. Sagu dan Kandungan Gizi sagu. Diakses pada tanggal 9 Desember 2019.

Irnawati, Muhammad Syahrul, Marlinda, Indah Eka Budiarti. 2018. Studi Pengolahan Sagu (Metroxylon sp) oleh Masyarakat Kampung Malawar Distrik Makbon Kabupaten Sorong. Jurnal Pengabdian kepada Masyarakat Volume 2 Nomor 1 Februari 2018.

Khaeriyah Darwis dan Andi Rahayu Anwar, 2018. Pelatihan Olahan Sawi Hijau Untuk Menubuhkan Jiwa Wirausaha pada Kelompok Wanita Tani MT. Almuhajirin di Kelurahan Tamalanrea Jaya. Vol. 1 Nomor 2 Tahun 2018. P-ISSN : 2598-1218, eISSN : 2598-1226. Jurnal Martabe Jurnal Pengabdian Kepada Masyarakat.

Mardikanto, Totok dan Poerwoko, Soebiato.,2013. Pemberdayaan Masyarakat dalam Persfektif Kebijakan Publik. Penerbit Alfabeta, Bandung.

Suryana, Achmad., 2014. Menuju Ketahanan Pangan Indonesia Berkelanjutan 2025, tantangan dan Penanganannya. Jurnal Forum Penelitian Agro Ekonomi, Volue 32 No.2, Desember 2014. Halaman 123-135. 